\title{
(Melek-Melekan ) In Birth Ceremony Of Tobanese Society At Kotapinang Village
}

\author{
Agata Murroisa P, Ichwan Azhari \\ Departement of Anthropology, \\ State University of Medan, Medan, Indonesia \\ Email: Amurroisa@gmail.com
}

\begin{abstract}
Kotapinang village, South Labuhan Batu regency. This type of research is using qualitative methods with an ethnographic approach. The goal of this research is to know the existence of Melekmelekan tradition in Kotapinang Village. The subjects for this research were all people who hold tradition in Kotapinang Village, This Research uses Ethnography method to found and collected all the facts in Tobanese society in kotapinang village related to Melek-melekan. From research conducted, the conclusion of tradition Melek-melekan persists in the midst of Kota Pinang Village society due to the card game that includes taking bets, and in the process has not changed much. The sentence of Melek-melekan is more popular than sentence Robu-robuan or Mamoholi (Batak) in the middle of Tobanese society in Kotapinang village have often heard people caused sentence Melekmelekan brought by the Javanese who are the majority people in Kotapinang village. In Tobanese religion, Melekmelekan tradition is used for drive evils out. Even though Tobanese society lives in modernity, they still held Melekmelekan caused the gambling game and to gather the society in that village. The goals of Melek-melekan to drive the evils out was getting disappeared.
\end{abstract}

Keywords: Melek-melekan, Robu-robuan, Lifecircle, Kotapinang, Tobanese.

\section{INTRODUCTION}

Organizing ceremonies of the life cycle are important for people to build human civilization. Every traditional ceremony is one container activities maintaining and preserving life and life is manifested in human relationships with the environment. Rite human life cycle in principle function as an activity to reawaken the spirit of the social life of the community. The social life in every society in the world repeatedly, at regular intervals, requiring what is called regeneration or the spirit of social life.

Lifecycle ceremonies were performed and the observed, giving a phenomenon that the life cycle is considered as a character of a state that has customs. For comparison the authors explore it as birth rites Batak tribe that inhabits South Labuhanbatu Regency, this is because in the process of the birth ceremony of Batak Toba society with its culture has experienced assimilation, acculturation and cultural diffusion with other ethnic groups who also inhabited the region of South Labuhanbatu regency. For seven days and seven nights of birth called a crisis or Robu-robuan (Koentjaraningrat 1985: 60), the ceremony seven days and nights that was formerly very popular Batak Toba to interact with other residents, because with time Robu-robuan (Koentjaraningrat1985: 60 ) relatives from far and close relatives of will come together so that it can be up to do to people who are rarely met.

Toba Batak society in Kota Pinang Village is looking forward to the seven days. Seven-day period is known as the popularity of Melek-melekan (Rajamarpodang.338). For the citizens of Batak Toba South Labuhan Batu Regency Village Kota Pinang, this event is always filled with playing cards of citizens who usually wears bet money on it, the game is held after the mother gives birth. The phenomenon is when a busy family will welcome a new member in their household. Communities will also be ready to gather in the house to gamble. During the crisis period (seven days, seven nights), population(Huta) alternately gathered at the home of parents of the baby every night. The point is that there are always people who maintain, that ghosts and evil spirits do not interfere or take the baby according to the Batak Toba ethnic beliefs.

It is very interesting to study is the birth of a series of ceremonies to welcome new members who do Batak Toba Village Kota Pinang."Melek-melekkan". The 
terms contained in the book Dalihan Natolu and Basic Principles Culture Batak (Rajamarpodang, 1985: 338) is like a magnet and sentences are awaited for the fathers and the youth village in every village and in essence is to keep the mother and baby from interference ghost and evil spirits. "Melek-Melekan At the ceremony Birthplace Society Batak Toba in the village of Kota Pinang"

Based on the background mentioned above, the writer can identify the problem:

1. Ceremony of the life cycle of the Batak Toba people in the village of Kota Pinang, South Labuhanbatu Regency

2. Melek-melekan as part of the ceremony the birth of the Toba Batak people in the village of Kota Pinang, South Labuhanbatu Regency.

3. Toba Batak society ceremony. Melek-melekan

4. Processes and activities in Melek-melekan.

5. cultural development Melek-melekan in the community in the village of Batak Toba Kota Pinang, South Labuhanbatu Regency.

\section{METHODOLOGY}

To find a complete data considered in solving scientific problems. There is a concept of the kind of writing that authors make a referral, ie writing a qualitative approach Ethnographic writing. James P. Spradley (2006: 35) states that: Type a description of social science is based on observation, interviews, and so that essentially can portray Native viewpoint.

In addition to using qualitative writing with an emphasis on writing ethnography, the authors also conducted a study of literature(library research) to add data that have relevance to this writing. The data obtained in the form of books, journals, articles and other scholarly writings

\section{RESULT AND DISCUSSION}

\section{A. Village History Kota Pinang}

Based on the search of the website http://kotapinang.wordpress.com. South Labuhanbatu Regency is one of the regencies in North Sumatra province, where the autonomous region was established based on the principle of Pancasila and the 1945 Constitution which is identical with areca nut fruit was originally a form of empire. Sultanate Kota Pinang was originally named Sultanate Pinang Cloud. The first Sultan Sultan Batara Sinombah ruling is also called Guru Gorga Pinayungan Sultan, who had a tomb in Hotang Mumuk Pinang Cloud State. Sultan Batara Sinombah a descendant of the nature of Minang State Kabau
Pagaruyung named Sultan Alamsyah Syaifuddin. Who made a name attached to the Kota Pinang village along the river caused Barumun once fenced nut. So that when the village is also known by the fence Kota Pinang nut. Kota Pinang originally occupied the two major Highways and Tamba Dasopang former second power clan was evident from his legacy in the form of graves. Both of these clans who for years lived in the region. During the two tribes in power, squabbles arise even frequent fights between the two clans, as each wanted to dominate the region. Because can not dispute resolved, then they agree that power is transferred to the settlers in the area who are worthy of running the empire. They were both looking for people who are able to lead the region. When the search for who will be appointed a leader, at the time of the two genera found a newcomer named Guru Pinayungan. In accordance pledge, then the Guru Pinayungan was appointed a king and protect all people, including residents outside these two large clans. Guru Pinayungan believed to originate from the area Pagaruyung coming to the area was also full of mythical stories.

Along with the opening of the tobacco plantations in East Sumatra, by the Dutch colonial government brought many contract laborers who work in plantations. Newcomers are mostly ethnic Javanese and Chinese. South Labuhanbatu Regency so the place where the author will conduct research, many profitable with the opening of plantations during the reign of the Dutch East Indies. With the arrival of workers from the island of Java which generally tribe native Java. Then gradually Labuhanbatu District which was originally inhabited by the Malay community. With the advent of Java rate as workers for rubber and palm oil companies. Then the java tribal cultures to assimilate with the local tribes in the South Labuhan Batu Regency.

B.The Meaning and Function of Melek-Melekan for People Toba in the village of Kota Pinang

Migration ethnic communities Toba in the Village Kota Pinang bring tradition into the social traditions of their day-to-day, however, because of the number of people of Javanese ethnicity dominant ethnic other so that the cultural traditions of Java also dominate the everyday social life in the District of Kota Pinang.

In accordance with that have been outlined above, there has been a cultural acculturation in the community in the District of Kota Pinang, Village Kota Pinang. Associated with problems in this study, it can be analyzed that the tradition of literacy-melekan originally done by the Javanese community when there are family members who give birth. In the event Melek-melekan the 
citizens who are around the neighborhood and came to attend as well as the Malay community Coastal, Mandailings, and Batak Toba

\section{C.Process Activity on events Melek-melekan In The Past}

In general for the Batak Toba when the women give birth to the spontaneously, people who come in childbirth runs will be immediately reported to all the relatives, distant relatives, and close ones. This news will quickly spread from mouth to mouth. The question people when they heard the good news is Songon him? Which means what gender? The butet if born are girls and the unsok or the bursok if born was a baby boy. According to the book Koentjaraningrat, Transition Rites of Man, at the time pregnant women who had already given birth, the husband dropped a large piece of wood from the housetops to the page, then cut it up into small rods with an ax.

This ceremony is called the Manaho saganon, the sound of this ax, a marker for the rest of Huta that a baby has been born. Based on the results of author interviews with mothers Marliana being held tradition of literacy-melekan that:

"if the embers of this fire is attached right under the bed so evil spirits will not dare to approach, and warmth coming from the embers are used to warm the mother and baby

"Furthermore, when the ember is no longer removing the heat than the people who were near the mother who usually is in-laws or parents heat up the coals again. Handling of labor in the tradition of Batak, usually handled by a shaman (Sibaso)

According to the standpoint of culture, Clifford Geertz described the religion as a system of symbols that apply to set moods and motivations powerful, pervasive, and long battery inside man with formulating the concepts of a general order of existence and wrap these concepts with some kind of actuality, so that the moods and motivations that seem typical and realistic.

If the process that runs somewhat difficult birth, then the husband will decide all the straps, then rang the rifle (AMP 1898: 17), or sometimes the husband hit the floor just below the house where the wife was lying. The purpose of all these actions is that the birth was quick progress, due to a surprising sound will cause a sudden birth. Childbirth assisted by a traditional midwife village called Sibaso. After Sibaso cut the umbilical cord with a bamboo skin(sambilu), and then clean up the mother and her baby, and she bandaged the baby with a blanket(Ulos Batak) and then laid it beside his mother close to the fireplace (tataring) made specifically at birth was my husband. Fire fireplace lit continuously throughout the day by slowly for a few days to a week. The point is that the body of the mother and baby stay warm so quickly healthy again.

Safety value reflected what was done by the family whose members are pregnant and handled by traditional birth attendants. When the contents have reached the age of 7 months and 9 months, the family in question told the TBAs who were in the village. This notification is intended that at the time (in childbirth) the shaman can help so that the birth process is expected to run smoothly. This value is also reflected in penaruhan objects or goods that are believed to contain magical, like fruit gourd, strand jeringobangle (talisman), and a small knife.

The conformity with specific expertise is reflected in the division of tasks shaman. Duty female shaman launched and welcoming the baby from the mother's womb. Meanwhile, male shamans utter incantations behind the veil (outside the place of delivery), so that objects that have the magical power to function properly.

\section{D.Tradition Melek-melekan In The Now}

Tradition Melek-melekan in Kota Pinang village has become an activity that is inherited by the parents for a long time. This is because the presence of an understanding that it would be an honor if the traditionmelekan Literacy whole community came home that has a celebration, even if just to see the baby for a while.

But in its development, the fathers of the insert bets in the card game. In his spare time nature of the book by Fransiskus Simon. Celebration (festivity) that animates free time generally considered appealing because the essence of the celebration is the lack of effort, not to make a profit, without a target. So in his spare time, there are many celebrations and festivities is what spawned the game and creativity so that in relation to literacy-melekan because the fathers were patrolling those faced with the possibility of falling asleep.

The fathers expel sleepiness with playing cards so that with the length of their play. then the fathers are 
thinking to create a new creativity in the hope no one is sleepy at the time of playing cards then the fathers are entering into the bet of the card game. Because at first by Fransiskus Simon that they contain celebration leisure time in which there is no profit

Toba Batak people, when faced with events or divinity Melek-melekan that the anticipation is a card game. Because tradition Toba Batak society has experienced a shift is towards a mere ceremonial event by entering a card game with a variety of high stakes. That leisure time immemorial custody of the mother and the baby for seven days and seven nights is associated with black magic and the supernatural, because there just are not responsible for the agency tapped the young and in the interests of black magic. In fact, infants who die before the age of seven days can be made into materials by people who are not responsible.

When I do this writing about 18:00 pm the residents started to come home who have a celebration. Until its peak at $20.00 \mathrm{hrs}$, the residents have started to make small groups (stacks). According to my observations and interviews to everyone who comes to literacy-melekan came from a young age to older or who have already married.

Based on my observations, when the residents came to the house, which is at 18:00 hrs - 21.00 citizens who generally are the fathers would gather in the living room of the house, they will talk with citizens among young people with the parents. While the mother was near the mother and baby, and also tried to exchange experiences on how to care for a newborn child, nothing whatever be the prohibition. While the mothers are carrying or see the state of the baby, too often the author saw when one of the people that one clan with the mother of this baby comes, then he was massaging the feet of the mother.

This tradition is maintained amid the progress of the times that force communities to increasingly less likely to believe in things mystical, yet traditionmelekanLiteracy is still running in the midst of society with legalized gambling game indirectly by the public and law enforcement officials.

\section{CONCLUSION}

In accordance with the results observed participation which follows directly the implementation of tradition Melek-melekan,and also supported by the results of author interviews with all parties were very understanding about this tradition, the authors then formulate some things that a conclusion in this paper, namely:

1. the purpose of the implementation of the Literacymelekan in Kota Pinang Village community in addition to keeping the mother and baby from disruption spirits and that the baby is not suppressed his mother, but also as a directional gambling arena and also inculcate cooperate, help each other and mutual share with fellow resident of Village Kota Pinang

2.procession implementation Literacy-melekan began with the arrival of the mother and her newborn baby in his residence, and when night came, each citizen can visit the owner's home-melekan Melek, when the mother had arrived home then the citizens who came home the sec Spontaneous fig cut the chicken to be distributed according to the customary division (shelter).Furthermore, the father will cut wood and dropped it from the rooftops, but in its development in the village of Kota Pinang, tradition tataring this no longer exist.

3. In accordance with the results of my research, I concluded that the tradition-melekan Literacy is on the present and the past is not much changed. And in the end, this tradition only serves as a means of community interaction.

3. Midwives, Tengku, the village head, the head of customs, the youth and all citizens of the Village Kota Pinang was instrumental in the implementation of literacy-melekan.

4. It should be for everyone who has given birth to a child can carry tradition, Melek-melekan because with their tradition-melekan Literacy is the family who just gave birth feel that the people who come to his home for seven days and nights to keep the mother and baby and who won every round of the game to set aside money in a barrel, as a reply to the host has provided a place for them to play cards. is a symbol that implies respect other residents (a), as well as randomly distributed food, has also become a symbol that has to mean to be able to share with their fellow citizens.

\section{REFERENCES}

Richard Jenkins.Edition,2008. Second Social Identity.Field. Bina Media Pioneer.

Koentjaraningrat. 1980. Some of Basic Social Anthropology.Jakarta: Dian Rakyat. 
Balai Pustaka

1984. The culture of Java.Jakarta: PN

-------. 2009. Introduction to Anthropology

Agus, Bustanuddin. 2006. Religion in Human

Life.Jakarta: King Grafindo Persada.

Budhisantoso (1984: 28)

Geertz Clifford. 1983. Abangan, Pupils, Priyayi in the Java community.Jakarta:

Pustaka Jaya

1992. Interpretation of

Culture.Yogyakarta: Canisius

Geertz Hildred. 1981 Arts Culture and Community in Indonesia.Jakarta: Social Studies Foundation

Halimah .2004. Birth meaning to the Community Jambi.Riau Abadi Jaya

Herusatoto Boediono.2008.Symbolism Java.Yogyakarta:

Waves.Jakarta: Rineka
-Reserved.2007. Man and Culture in Indonesia.Jakarta:

Djambatan.

Koentjaraningrat. 1985.The rites transition in Indonesia.Jakarta: Dian Rakyat.

Mauss, Marcell.1992. Giving, Form and Function Exchange inSociety.Ancient Jakarta: Yayasan Obor Indonesia.

Moleong Lexy J. 2010. Qualitative Research Methods.Bandung: PT Young Rosdakarya.

Rajamarpodang. 1987. Basic Principles Dalihan Natolu and Batak culture.Bandung: Kencana Jaya 